Article

\title{
Electrocarboxylation of Dichlorobenzenes on a Silver Electrode in DMF
}

\author{
Pei-Pei Luo ${ }^{1}$, Ying-Tian Zhang ${ }^{1}$, Bao-Li Chen ${ }^{1, *}$ (D), Shu-Xian Yu ${ }^{1}$, Hua-Wei Zhou ${ }^{1}$, \\ Kong-Gang $\mathrm{Qu}{ }^{1}$, Yu-Xia Kong ${ }^{1}$, Xian-Qiang Huang ${ }^{1}$, Xian-Xi Zhang ${ }^{1, *}$ and Jia-Xing Lu ${ }^{2, *}$ \\ 1 Shandong Provincial Key Laboratory of Chemical Energy Storage and Novel Cell Technology, College of \\ Chemistry and Chemical Engineering, Liaocheng University, Liaocheng 252059, China; \\ luopeipeigood@163.com (P.-P.L.); lcuytz@126.com (Y.-T.Z.); yushuxian2020@yahoo.com (S.-X.Y.); \\ zhouhuaweiopv@163.com (H.-W.Z.); kgqu1985@gmail.com (K.-G.Q.); kongyuxia1212@163.com (Y.-X.K.); \\ hxqqxh2008@163.com (X.-Q.H.) \\ 2 Shanghai Key Laboratory of Green Chemistry and Chemical Processes, School of Chemistry and Molecular \\ Engineering, East China Normal University, Shanghai 200062, China \\ * Correspondence: goodchenbaoli@163.com (B.-L.C.); xxzhang3@126.com (X.-X.Z.); \\ jxlu@chem.ecnu.edu.cn (J.-X.L.); Tel.: +86-635-823-0647 (B.-L.C.); +86-635-823-0680 (X.-X.Z.); \\ +86-21-6223-3491 (J.-X.L.)
}

Received: 25 August 2017; Accepted: 13 September 2017; Published: 15 September 2017

\begin{abstract}
Carbon dioxide $\left(\mathrm{CO}_{2}\right)$ is the largest contributor to the greenhouse effect, and fixing and using this greenhouse gas in a facile manner is crucial. This work investigates the electrocarboxylation of dichlorobenzenes with the atmospheric pressure of $\mathrm{CO}_{2}$ in an undivided cell with an $\mathrm{Ag}$ cathode and an $\mathrm{Mg}$ sacrificial anode. The corresponding carboxylic acids and their derivatives, which are important industrial and fine chemicals, are obtained. To deeply understand this reaction, we investigate the influence of various reaction conditions, such as supporting electrolyte, current density, electric charge, and reaction temperature, on the electrocarboxylation yield by using 1,4-dichlorobenzene as the model compound. The electrochemical behavior of dichlorobenzenes is studied through cyclic voltammetry. The relation among the distinct electronic effects of dichlorobenzenes, the electrochemical characteristics of their reduction, and the distribution law of target products is also established.
\end{abstract}

Keywords: $\mathrm{CO}_{2}$; electrocarboxylation; dichlorobenzenes; silver electrode

\section{Introduction}

The growing carbon dioxide $\left(\mathrm{CO}_{2}\right)$ content in the atmosphere is the major contributor to the greenhouse effect and global warming [1]. Measures to address the greenhouse effect can be implemented in two ways. The first one is to create a low-carbon economic development model that conserves energy and controls energy from the source. The second method is to convert $\mathrm{CO}_{2}$ into useful organic chemicals [2-4]. Continuous emission of $\mathrm{CO}_{2}$ is expected to occur for a long time due to human dependence on fossil fuel. Therefore, identifying effective means to convert and utilize $\mathrm{CO}_{2}$ has become a pressing issue in this modern society; moreover, the fixation of $\mathrm{CO}_{2}$ into useful products of industrial significance has elicited considerable attention [5-9].

Although $\mathrm{CO}_{2}$ is the main gas that causes the greenhouse effect, $\mathrm{CO}_{2}$ is an abundant, cheap, non-toxic, recyclable $\mathrm{C} 1$ building block for organic synthesis. However, $\mathrm{CO}_{2}$ conversion is a challenge to chemists because of the high chemical and thermodynamic stability of this gas. Electrochemical techniques [10] that deal with a clean reagent, the electron, can realize $\mathrm{CO}_{2}$ activation at normal temperature and pressure [11-13]. Therefore, electrocarboxylation is a facile method of $\mathrm{CO}_{2}$ fixation from ecological and economic viewpoints. Many substrate types, alcohols [14], epoxides [15,16], 
imines [17], organic halides [13,18-28], ketones [11,12,29-32], aldehydes [33], alkenes [34-38], and alkynes [39] have been used in previous studies.

Carboxylic acids and their derivatives are an important class of compounds, and several of them are fine chemicals of industrial interest, especially in the production of anti-inflammatory drugs. Electrocarboxylation of organic halides is a potential facile means to synthesize carboxylated products. Homogeneous [40-42] and heterogeneous [19,21,22,43,44] catalytic methods have been adopted to optimize this reaction because of the negative reduction potential of organic chlorides. A good catalytic electrode material can effectively reduce the reduction potential and improve the reaction. $\mathrm{Hg}$ has been the main material choice for a long time. However, $\mathrm{Hg}$ is discarded for environmental reasons. Meanwhile, studies have indicated that silver (Ag) exhibits extraordinary electrocatalytic activities toward the reduction of organic halides $[13,18-23,43,44]$. Although many studies have investigated electroreduction and electrocarboxylation of organic chlorides, most of them focused on monochloride compounds $[19,21,22,40-44]$. Only a few studies have examined the electroreduction of polyhalidecompounds [45-59], such as dichloromethane, trichloromethane, tetrachloromethane, and hexachlorocyclohexane.

In this study, electroreduction of dichlorobenzenes on an Ag electrode in the presence of $\mathrm{CO}_{2}$ under mild conditions is described (Scheme 1). The aim of this investigation is to set up an alternative methodology for electrocarboxylation of dichlorobenzenes with $\mathrm{CO}_{2}$ to the corresponding carboxylic acid, thus providing an environmentally friendly method for the electrochemical fixation of $\mathrm{CO}_{2}$ with dichlorobenzenes possessing aromatic carboxylic acids and their derivatives, which are useful for pharmaceutical or industrial application.

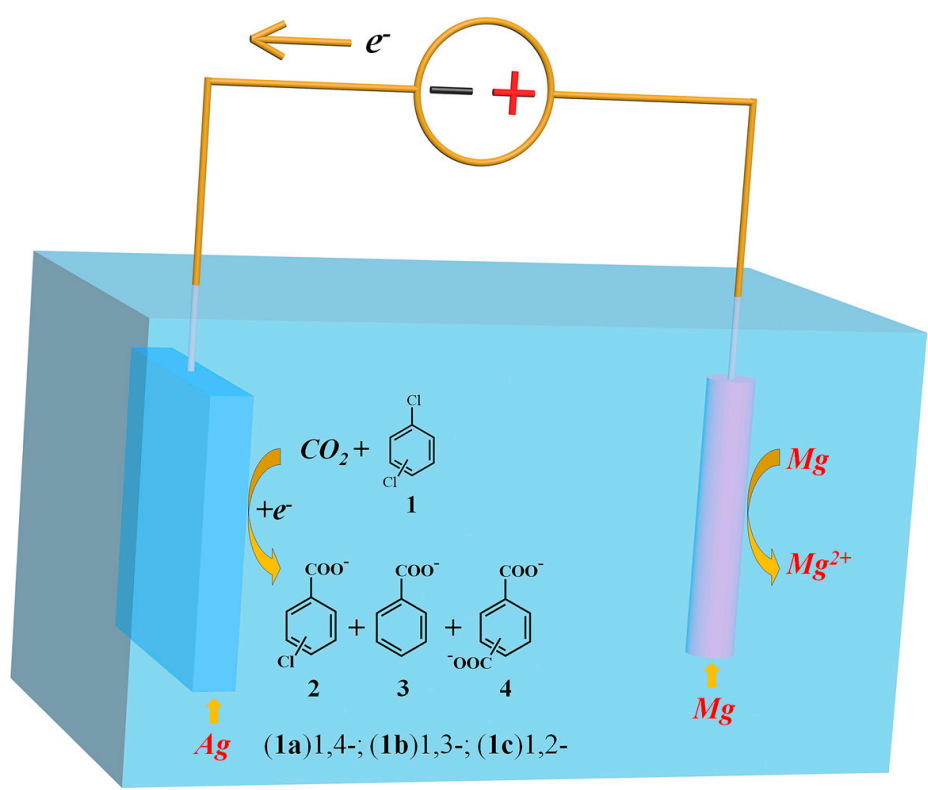

Scheme 1. Electrocarboxylation of dichlorobenzenes.

\section{Results and Discussion}

\subsection{Electroanalytical Measurement of 1,4-Dichlorobenzene}

Figure 1 presents the voltammetric characteristic of 1,4-dichlorobenzene (1a) in $\mathrm{N}, \mathrm{N}$-dimethylformamide (DMF) containing $0.1 \mathrm{M}$ tetraethylammonium tetrafluoroborate $\left(\mathrm{TEABF}_{4}\right)$ on glassy carbon (GC), and Ag electrodes at a scan rate of $0.1 \mathrm{~V} / \mathrm{s}$. As shown in curve a, no redox peak on the GC electrode existed within the scan range, which revealed a favorable potential window in the region of -0.6 to $-2.5 \mathrm{~V}$. Two successive irreversible cathodic peaks were detected at $-2.04 \mathrm{~V}$ and $-2.30 \mathrm{~V}$ (curve $\mathrm{b}$ ) after $1 \mathrm{a}$ was added to the solution. The first reduction peak currents varied 
linearly with $v^{1 / 2}$ (Figure S1, Supplementary Materials), which confirmed the diffusion control for the electroreduction process. The voltammetric characteristic of chlorobenzene on the GC electrode was also recorded for comparison. Curve c displayed an irreversible reduction peak at $-2.30 \mathrm{~V}$ corresponding to the two-electron transfer of the $\mathrm{C}-\mathrm{Cl}$ bond of chlorobenzene, similar to the second reduction peak of $\mathbf{1 a}$ on the GC electrode [50]. This result implies that the first cathodic peak was caused by the two-electron reductive cleavage of one of the $\mathrm{C}-\mathrm{Cl}$ bonds, and the second one was caused by the reduction of another $\mathrm{C}-\mathrm{Cl}$ bond. The gas chromatography-mass spectrometry (GC-MS) analysis also confirmed the synthesis of chlorobenzene through potentiostatic electrolysis at the first reduction peak in the presence of $\mathrm{N}_{2}$. When the voltammetric characteristic of $1 \mathrm{a}$ was recorded in DMF saturated with $\mathrm{CO}_{2}(0.2 \mathrm{M})$ [51], a different behavior was observed. As shown in curve d of Figure 1, the first reduction peak current increased, with its potential appreciably shifting to a more positive place, indicating that a chemical reaction may have occurred between the electroreduced intermediate and $\mathrm{CO}_{2}$. Meanwhile, the second reduction peak disappeared. The voltammetric characteristic of 1a was checked on the Ag electrode for comparison. As shown in curves b and e, the two reduction peaks shifted to a more positive potential because of the electrocatalytic properties of the Ag electrode. The electrocatalytic activities of electrode materials for the reduction of organic halides have been the subject of many studies $[18,19,21,22,52-54]$. These studies have shown that Ag exhibits powerful electrocatalytic activities toward the reduction of various organic halides. Therefore, the electroreduction of dichlorobenzenes on the Ag cathode was investigated herein.
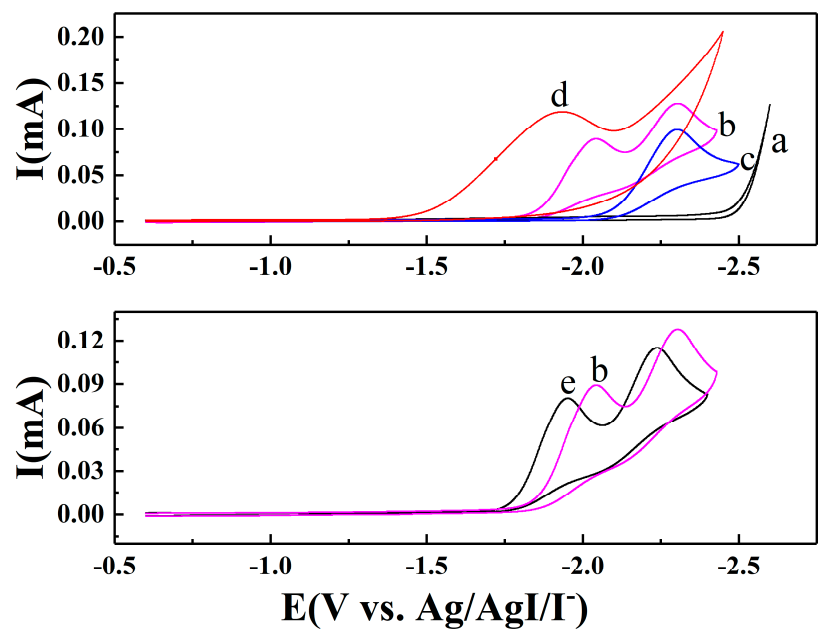

Figure 1. Cyclic voltammograms obtained with the scan rate of $0.1 \mathrm{~V} / \mathrm{s}$ in $\mathrm{DMF}+0.1 \mathrm{M} \mathrm{TEABF}_{4}$ : (a) blank cyclic voltammetry on GC electrode; (b) as (a) $+5 \mathrm{mM}$ 1,4-dichlorobenzene; (c) as (a) $+5 \mathrm{mM}$ chlorobenzene; (d) as (b) in the presence of $\mathrm{CO}_{2}$; (e) cyclic voltammetry of $5 \mathrm{mM}$ 1,4-dichlorobenzene on Ag electrode.

\subsection{Electrocarboxylation of Dichlorobenzene}

Considering that electrolysis carried out under galvanostatic conditions is a much more convenient procedure than that implemented under potentiostatic conditions, the reaction conditions for the galvanostatic electrolysis of $\mathbf{1 a}$ were examined and are summarized in Table 1. The yields of mono- and di-carboxylation products were affected by the choice of supporting electrolyte (SE), current density $(J)$, electric charge $(Q)$, and reaction temperature $(T)$.

SE strongly determined the effects of the electrocarboxylation of 1a. Tetrabutyl ammonium chloride (TBACl) was the best SE, and resulted in 36.7\% total electrocarboxylation yield (Table 1, entry 5). Notably, with the same tetraalkylammonium cation, the total carboxylation yield dependences on the anion were in the following order: $\mathrm{Cl}^{-1}>\mathrm{Br}^{-1}>\mathrm{I}^{-1}$ (Table 1, entries 1-3, 5-7). Although negatively charged in the Ag electrode, inorganic halide anions have been reported to remain 
powerfully absorbed in the Ag electrode in the sequence of $\mathrm{Cl}^{-1} \leq \mathrm{Br}^{-1} \leq \mathrm{I}^{-1}$ and are thus accorded with many well-known halide properties, such as the solubility of products with Ag ions $[18,55]$. In addition, with the same anion of $\mathrm{Cl}^{-1}, \mathrm{Br}^{-1}$, and $\mathrm{I}^{-1}$, the synthesis carried out with the $\mathrm{TBA}^{+}$cation provided better yields than those of the TEA ${ }^{+}$cation cases (Table 1, entries 1-3, 5-7), indicating that the cations exerted some influence on the electrolysis.

Table 1. Electrocarboxylation of 1,4-dichlorobenzene under various synthetic parameters ${ }^{\text {a }}$.

\begin{tabular}{|c|c|c|c|c|c|c|c|c|}
\hline \multirow{2}{*}{ Entry } & \multirow{2}{*}{ SE } & \multirow{2}{*}{$J\left(\mathrm{~mA} / \mathrm{cm}^{2}\right)$} & \multirow{2}{*}{$Q(\mathrm{~F} / \mathrm{mol})$} & \multirow{2}{*}{$T\left({ }^{\circ} \mathrm{C}\right)$} & \multicolumn{3}{|c|}{ Carboxylation Product Yields (\%) ${ }^{b}$} & \multirow{2}{*}{ Total Yield $(\%)^{b}$} \\
\hline & & & & & 2 & 3 & 4 & \\
\hline 1 & TEACl & 10 & 4 & 0 & 3.1 & trace & 1.0 & 4.1 \\
\hline 2 & TEABr & 10 & 4 & 0 & 2.1 & trace & 1.0 & 3.1 \\
\hline 3 & TEAI & 10 & 4 & 0 & 1.2 & trace & 1.0 & 2.2 \\
\hline 4 & TEABF4 & 10 & 4 & 0 & 2.3 & trace & trace & 2.3 \\
\hline 5 & TBACl & 10 & 4 & 0 & 31.2 & 3.2 & 2.3 & 36.7 \\
\hline 6 & TBABr & 10 & 4 & 0 & 24.3 & 3.4 & 2.4 & 30.1 \\
\hline 7 & TBAI & 10 & 4 & 0 & 25.3 & trace & 1.0 & 26.3 \\
\hline 8 & TBACl & 8 & 4 & 0 & 16.1 & 4.2 & 2.2 & 22.5 \\
\hline 9 & TBACl & 13 & 4 & 0 & 35.7 & 4.3 & 2.9 & 42.9 \\
\hline 10 & TBACl & 14 & 4 & 0 & 37.6 & 3.3 & 2.7 & 43.6 \\
\hline 11 & TBACl & 15 & 4 & 0 & 34.4 & 4.9 & 3.3 & 42.6 \\
\hline 12 & TBACl & 16 & 4 & 0 & 26.8 & 2.6 & 2.2 & 31.6 \\
\hline 13 & TBACl & 14 & 2 & 0 & 14.9 & 2.6 & 1.7 & 19.2 \\
\hline 14 & TBACl & 14 & 3 & 0 & 23.0 & 2.6 & 1.6 & 27.2 \\
\hline 15 & TBACl & 14 & 4.2 & 0 & 37.2 & 4.7 & 3.4 & 45.3 \\
\hline 16 & TBACl & 14 & 4.5 & 0 & 26.8 & 3.9 & 2.3 & 33.0 \\
\hline 17 & TBACl & 14 & 5 & 0 & 24.8 & 3.5 & 2.2 & 30.5 \\
\hline 18 & TBACl & 14 & 4.2 & -10 & 41.6 & 1.0 & 1.0 & 43.6 \\
\hline 19 & TBACl & 14 & 4.2 & -5 & 40.7 & 1.9 & 1.8 & 44.4 \\
\hline 20 & TBACl & 14 & 4.2 & 5 & 38.4 & 4.6 & 3.3 & 46.3 \\
\hline 21 & TBACl & 14 & 4.2 & 10 & 38.6 & 4.1 & 3.1 & 45.8 \\
\hline 22 & TBACl & 14 & 4.2 & 25 & 24.2 & 6.7 & 3.1 & 34.0 \\
\hline
\end{tabular}

${ }^{a}$ General conditions: $\mathrm{DMF}=10 \mathrm{~mL}, \mathrm{SE}=0.1 \mathrm{M}, 1,4$-dichlorobenzene $=0.1 \mathrm{M}, \mathrm{Ag}$ as cathode, $\mathrm{Mg}$ as anode,

$P_{\mathrm{CO}_{2}}=1 \mathrm{~atm} ;{ }^{\mathrm{b}}$ The yield based on starting substrate is determined by GC.

The electrocarboxylation yields were also strongly affected by $J$ (Table 1 , entries $5,8-12$ ). The highest total electrocarboxylation yield of $43.6 \%$ was achieved with $14 \mathrm{~mA} / \mathrm{cm}^{2}$ (Table 1, entry 10). The total electrocarboxylation yield decreased regardless of whether the current density was higher or lower than $14 \mathrm{~mA} / \mathrm{cm}^{2}$. On the one hand, the electrode potential became negative when the current density was high. Hence a series of side reactions, such as the reduction of $\mathrm{Mg}^{2+}$ or $\mathrm{CO}_{2}$ to $\mathrm{C} 1$ or $\mathrm{C} 2$ compounds (carbonate, oxalate, and $\mathrm{CO}$ ), occurred on the electrode surface and reduced the total electrocarboxylation yield [56]. On the other hand, the electrode potential became positive when current density was low. Therefore, the proportion of the Faradaic current was reduced, thus decreasing the carboxylation yield.

The influence of $Q$ was also investigated (Table 1, entries 10,13-17). The Faradaic efficiency did not reach $100 \%$ due to the existence of non-Faradaic current. Accordingly, an amount that is more than the theoretic charge was consumed to improve the yield in general. The best total yield of $45.3 \%$ was obtained when the passed electric charge reached $4.2 \mathrm{~F} / \mathrm{mol}$ (Table 1, entry 15). Before the point of $4.2 \mathrm{~F} / \mathrm{mol}$, the total yield increased rapidly with the increase in the passed charge. Afterward, the total yield decreased to $30.5 \%$ for $5 \mathrm{~F} / \mathrm{mol}$.

$T$ also influenced the electrolysis reaction and mainly affected the thermodynamics and kinetics of the electrocarboxylation reaction and the solubility of $\mathrm{CO}_{2}$ in the solvent [51]. In general, a low $T$ increases the solubility of $\mathrm{CO}_{2}$ in $\mathrm{DMF}$, and is conducive to the reaction. A low $T$ also reduces the rate of mass transport and increases the activation energy of the reaction, both of which are dangerous to the electrocarboxylation of 1a. To investigate the effect of $T$, a set of electrolysis experiments were carried out at different $T$ values (Table 1, entries 15, 18-22). Increasing $T$ from $-10{ }^{\circ} \mathrm{C}$ to $5{ }^{\circ} \mathrm{C}$ favored 
the reaction, but further increasing $T$ resulted in a low total carboxylation yield of $1 \mathbf{a}$. The best total carboxylation product with $46.3 \%$ yield was achieved at $5{ }^{\circ} \mathrm{C}$ (Table 1 , entry 20).

\subsection{Electrocarboxylation of Other Dichlorobenzenes}

To investigate the effect of the $\mathrm{C}-\mathrm{Cl}$ bond position on the benzene ring, cyclic voltammograms and electrolysis were extended to 1,3-dichlorobenzene (1b) and 1,2-dichlorobenzene (1c) under the optimized reaction conditions.

As shown in Figure 2, two successive irreversible cathodic peaks corresponding to the two-electron transfer reaction of the $\mathrm{C}-\mathrm{Cl}$ bond were detected for all the three dichlorobenzenes on the Ag electrode. The cathodic peak potentials of the three dichlorobenzenes were very close. Electrolysis of $\mathbf{1 b}$ and $\mathbf{1 c}$ was conducted under the optimized conditions. As shown in Table 2, halogenated monocarboxylation product 2 was obtained for all the three dichlorobenzenes, and the yield of 2 decreased from $43.7 \%$ to $38.4 \%$ in the following order: $\mathbf{2} \mathbf{c}>\mathbf{2 b}>\mathbf{2 a}$. The yield correlated with the first peak current of 1 (Figure 2): 1c $(0.103 \mathrm{~mA})>\mathbf{1 b}(0.097 \mathrm{~mA})>\mathbf{1 a}(0.079 \mathrm{~mA})$. High yields were obtained when the first peak current of 1 was large. In addition, dehalogenated monocarboxylation product 3 was detected for all the three dichlorobenzenes. Surprisingly, dicarboxylation products $4 \mathrm{~b}$ and $4 \mathrm{c}$ were not detected. To understand this phenomenon, the proposed pathways for the electrocarboxylation of dichlorobenzene were studied, and energy calculations were performed using the Gaussian09W program (Revision A.1, Gaussian, Inc., Wallingford, CT, USA, 2009).

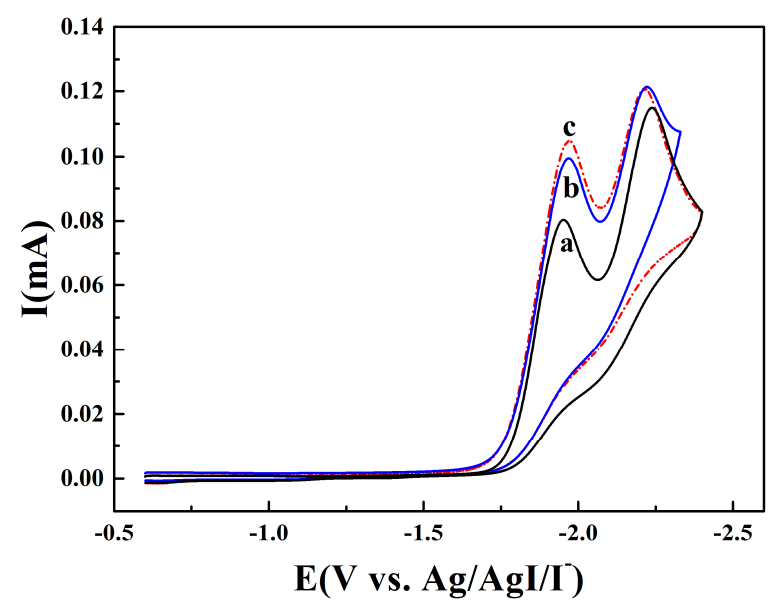

Figure 2. Cyclic voltammograms of $5 \mathrm{mM}$ dichlorobenzene obtained on Ag electrode with the scan rate of $0.1 \mathrm{~V} / \mathrm{s}$ in $\mathrm{DMF}+0.1 \mathrm{M} \mathrm{TEABF}_{4}$-: (a) 1,4-dichlorobenzene; (b) 1,3-dichlorobenzene; (c) 1,2-dichlorobenzene.

Table 2. Electrocarboxylation of dichlorobenzenes ${ }^{\text {a }}$.

\begin{tabular}{cccccc}
\hline \multirow{2}{*}{ Entry } & \multirow{2}{*}{ Substrate } & \multicolumn{3}{c}{ Carboxylation Product Yields (\%) } & \multirow{2}{*}{ Total Yield (\%) } \\
\cline { 3 - 5 } & & $\mathbf{2}$ & $\mathbf{3}$ & $\mathbf{4}$ & \\
\hline 1 & 1,4-dichlorobenzene (1a) & 38.4 & 4.6 & 3.3 & 46.3 \\
2 & 1,3-dichlorobenzene (1b) & 41.4 & 7.8 & 0 & 49.2 \\
3 & 1,2-dichlorobenzene (1c) & 43.7 & 5.8 & 0 & 49.5 \\
\hline
\end{tabular}

a General conditions: DMF $=10 \mathrm{~mL}, \mathrm{TBACl}=0.1 \mathrm{M}$, haloacetophenone $=0.1 \mathrm{M}, Q=4.2 \mathrm{~F} / \mathrm{mol}, J=14 \mathrm{~mA} / \mathrm{cm}^{2}$, $T=5^{\circ} \mathrm{C}, P_{\mathrm{CO}_{2}}=1 \mathrm{~atm}, \mathrm{Ag}$ as cathode, $\mathrm{Mg}$ as anode; ${ }^{\mathrm{b}}$ The yield based on starting substrate is determined by GC.

For monoaromatic halide compounds, carboxylated products were normally obtained by the reaction of $\mathrm{CO}_{2}$ with the anions that were generated by the two-electron transfer of monoaromatic halides $[20,25,57,58]$. Therefore, the possible electrocarboxylation pathway of dichlorobenzene is Scheme 2. The first electron reduction of $\mathbf{1}$ results in the carbon radical 5. After the second electron 
transfer, 5 is reduced to carbon anion 6, which reacts with $\mathrm{CO}_{2}$ to form halogenated monocarboxylation product 2 . The phenomenon in which two successive irreversible cathodic peaks were detected for all the three dichlorobenzenes (Figure 2) is indicative of two two-electron transfer reactions for all three dichlorobenzenes. Therefore, 2 may undergo further two-electron transfer to the corresponding carbon anion 8, which would react with another $\mathrm{CO}_{2}$ to form decarboxylation product 4 . Given that a small amount of water is still present in the solvent, the protonation process competes with carboxylation $[13,58,59]$. Then, dehalogenated monocarboxylation product $\mathbf{3}$ is formed by either carboxylation following protonation or protonation following carboxylation.

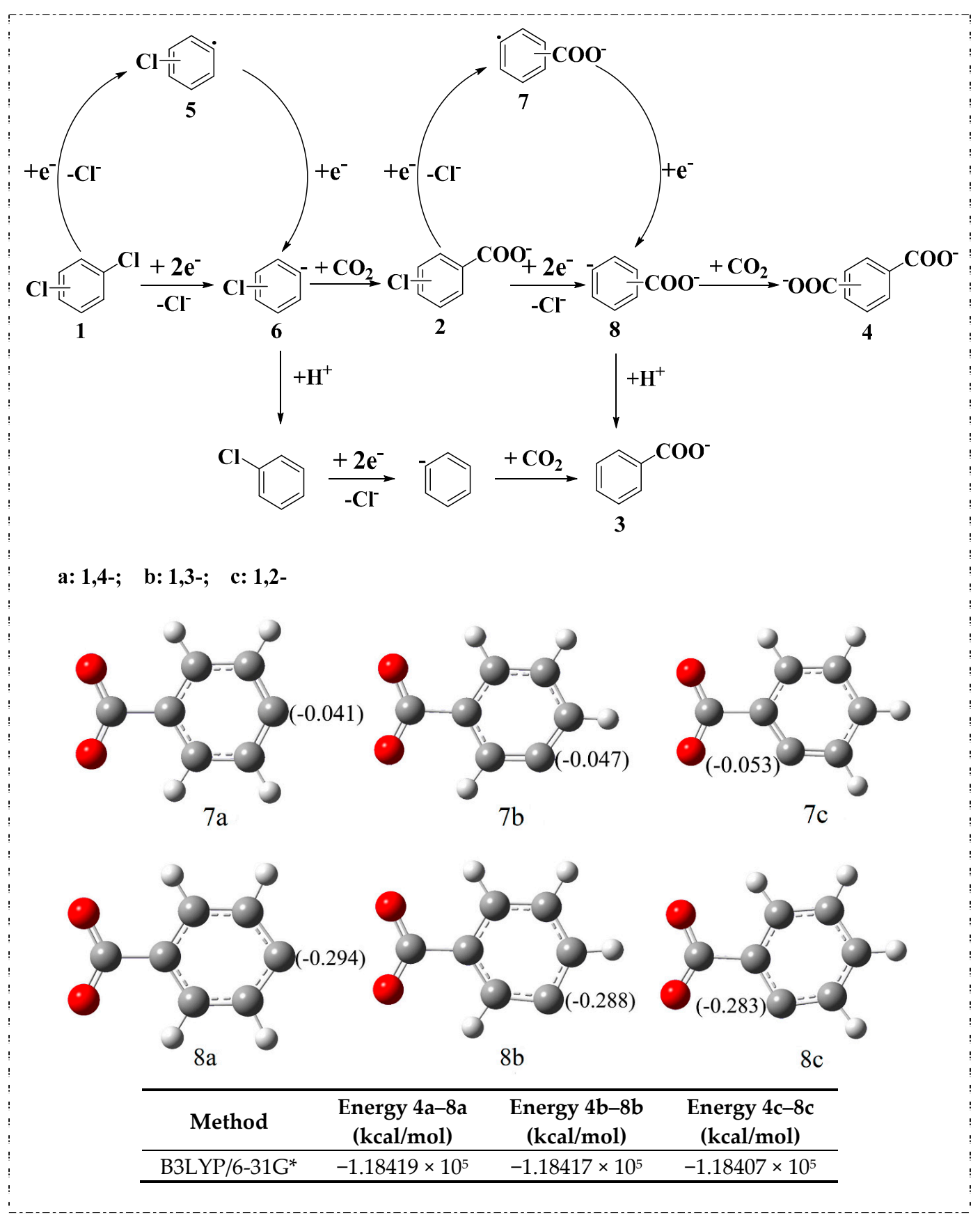

Scheme 2. Proposed pathways for electrocarboxylation of dichlorobenzenes (Insertion: Optimized structures of expected carboxylated intermediate for dichlorobenzenes, grey- $\mathrm{C}$ atom, red-O atom, white-H atom). 
On the basis of the electrolysis result (Table 2) and the proposed electrocarboxylation pathway, dicarboxylation products $4 b$ and $4 c$ were not obtained from $\mathbf{1 b}$ and $\mathbf{1 c}$, respectively. This finding indicates that several steps may have been blocked from $2 b$ to $4 \mathbf{b}$ and from $2 c$ to $4 \mathbf{c}$. To determine the reason, the Gaussian09W program was used to perform gas-phase geometry optimizations and energy calculations using the density functional theory (DFT) B3LYP /6-31G* method [60]. The optimized structures with the net charges on the carbon radicals are shown in Scheme 2. The charge numbers of the carbon radical of $7 \mathbf{a}, 7 \mathbf{b}$, and $7 \mathbf{c}$ were $-0.041,-0.047$, and -0.053 , respectively. Electrophilicity decreased in the following order: $7 a>7 b>7 c .8$ was difficult to obtain with weak electrophilicity. Generally, strong electron donation of the substrate goes against electrocarboxylation [29]. When $\mathbf{1 b}$ or $\mathbf{1 c}$ was used as a substrate, the weak electrophilicity of the carbon radical of $\mathbf{7 b}$ or $\mathbf{7 c}$ might have significantly prevented $\mathbf{7 b}$ or $\mathbf{7 c}$ from undergoing further one-electron transfer to the corresponding carbon anion $\mathbf{8 b}$ or $\mathbf{8 c}$. Scheme 2 indicates that the charge numbers of the carbon anion of $\mathbf{8 a}, \mathbf{8 b}$, and $8 c$ were $-0.294,-0.288$, and -0.283 , respectively. Nucleophilicity decreased in the following order: $8 a>8 b>8 c$. When the electrocarboxylation was carried out using $\mathbf{1 b}$ or $1 \mathrm{c}$ as a substrate, the weak nucleophilicity of the carbon anion of $\mathbf{8 b}$ or $8 \mathbf{c}$ might have prevented $\mathbf{8 b}$ or $8 \mathbf{c}$ from attacking $\mathrm{CO}_{2}$ in a nucleophilic manner even when a small amount of $\mathbf{8 b}$ or $\mathbf{8} \mathbf{c}$ was generated [18]. Furthermore, based on the energy calculations, the energy differences of $\mathbf{4 b - 8 b}$ and $\mathbf{4 c - 8 c}$ were surprisingly higher than that of $\mathbf{4 a - 8 a}$ (Scheme 2). Accordingly, the gas-phase geometry optimizations and energy calculations corroborated the phenomenon that the corresponding dicarboxylation products, $4 \mathbf{b}$ and $4 \mathbf{c}$, were not obtained.

Our investigation of the electrocarboxylation of dichlorobenzenes on an $\mathrm{Ag}$ electrode showed that the initial stage was the formation of carbon anions that could attack $\mathrm{CO}_{2}$ in a nucleophilic manner to form halogenated monocarboxylation product 2 or dehalogenated monocarboxylation 3 . Afterward, 2 was further reduced by another two-electron transfer followed by a reaction with $\mathrm{CO}_{2}$ to form dicarboxylation product 4 , or by protonation to 3 . The electronic effect of different $\mathrm{C}-\mathrm{Cl}$ bond positions on the benzene ring played a decisive role in reaction efficiency and product distribution. When 1a was used as a substrate, three carboxylation products were obtained. By contrast, no dicarboxylation product was available for $\mathbf{1} \mathbf{b}$ or $\mathbf{1} \mathbf{c}$ when the electrophilicity of the corresponding carbon radical, and the nucleophilicity of the corresponding carbon anion, were weak.

\section{Materials and Methods}

\subsection{Materials and Product Measurement}

All dichlorobenzenes were commercially available from J\&K Chemical Co. (Beijing, China). DMF was kept over $4 \AA$ molecular sieves. All other reagents were used as received. The cyclic voltammograms were measured with a $\mathrm{CHI} 760 \mathrm{E}$ electrochemical station (Shanghai Chenhua Instruments Co., Shanghai, China) at $25^{\circ} \mathrm{C}$ in an undivided glass cell equipped with a gas inlet and outlet. Galvanostatic electrolysis was performed with a DC-regulated power supply HY5003M (Hangzhou Huayi Electronics Industry Co., Ltd., Hangzhou, China) in an undivided glass cell. The product yields were determined through GC-2014C gas chromatography (GC) (SHIMADZU, Tokyo, Japan).

\subsection{General Electroanalytical Procedure}

The electroanalytical experiments were performed in a DMF solution containing $0.1 \mathrm{M} \mathrm{TEABF}_{4}$ as the SE. The working electrodes used for the electroanalytical experiments were GC with a diameter of $2 \mathrm{~mm}$ and $\mathrm{Ag}(d=2 \mathrm{~mm})$. The auxiliary and reference electrodes were a platinum (Pt) spiral and $\mathrm{Ag} / \mathrm{AgI} / 0.1 \mathrm{M}$ TBAI in DMF, respectively. All experiments were performed at atmospheric pressure. 


\subsection{General Electrolysis Procedure}

Galvanostatic electrolysis was conducted in a mixture of dichlorobenzenes $(0.1 \mathrm{M})$ and SE $(0.1 \mathrm{M})$ in $10 \mathrm{~mL}$ DMF solvent saturated with $\mathrm{CO}_{2}$ in an undivided electrochemical cell equipped with an $\mathrm{Ag}$ cathode $\left(8 \mathrm{~cm}^{2}\right)$ and a sacrificial $\mathrm{Mg}$ anode. At the end of each set of experiments, the reaction mixture was esterified in DMF by adding anhydrous $\mathrm{K}_{2} \mathrm{CO}_{3}(2 \mathrm{mmol})$ and $\mathrm{MeI}(9 \mathrm{mmol})$ at $55^{\circ} \mathrm{C}$ for $5 \mathrm{~h}$. Then, the solution was hydrolyzed and extracted with diethyl ether, and the combined organic layers were dried over anhydrous $\mathrm{MgSO}_{4}$, filtered, and evaporated. The yields of methyl esters corresponding to acids were determined via GC with decane as the internal standard.

\section{Conclusions}

We demonstrated a simple and efficient electrochemical means to achieve the electroreduction of dichlorobenzenes in the presence of $\mathrm{CO}_{2}$ on an Ag electrode. The impact of SE, J, Q, and $T$ on the total electrocarboxylation yield was studied with 1,4-dichlorobenzene as the model compound. The electronic effect of different $\mathrm{C}-\mathrm{Cl}$ bond positions on the benzene ring played a decisive role in reaction efficiency and product distribution. This work provides an environmentally friendly method for the electrochemical fixation of $\mathrm{CO}_{2}$ with dichlorobenzenes possessing aromatic carboxylic acids and their derivatives, which are useful for pharmaceutical or industrial use. Thus, the applications of electrochemical methodology are expanded.

Supplementary Materials: The following are available online at www.mdpi.com/2073-4344/7/9/274/s1, Figure S1: Cyclic voltammograms of $5 \mathrm{mM}$ 1,4-dichlorobenzene in DMF containing $0.1 \mathrm{M}$ TEABF 4 on $\mathrm{GC}$ electrode at (a) $\mathrm{v}=0.1 \mathrm{~V} / \mathrm{s}$; (b) $0.2 \mathrm{~V} / \mathrm{s}$; (c) $0.3 \mathrm{~V} / \mathrm{s}$; (d) $0.4 \mathrm{~V} / \mathrm{s}$; (e) $0.5 \mathrm{~V} / \mathrm{s}$; (f) $0.6 \mathrm{~V} / \mathrm{s}$; (g) $0.7 \mathrm{~V} / \mathrm{s}$; (h) $0.8 \mathrm{~V} / \mathrm{s}$; (i) $0.9 \mathrm{~V} / \mathrm{s}$ and (j) $1.0 \mathrm{~V} / \mathrm{s}$.

Acknowledgments: This work was financially supported by the funds from the National Natural Science Foundation of China (21503104, 21601078, 21401094), Natural Science Foundation of Shandong Province (ZR2014BQ010, ZR2016BQ20, ZR2016BQ21), Science and Technology Development Project Fund of Liaocheng (2014GJH08), Research Fund for the Doctoral Program of Liaocheng University (31805), and Colleges and Universities in Shandong Province Science and Technology Projects (J16LC05, J17KA097).

Author Contributions: Pei-Pei Luo, Ying-Tian Zhang and Bao-Li Chen conceived of and designed the experiments. Pei-Pei Luo, Ying-Tian Zhang, Bao-Li Chen, Shu-Xian Yu, Hua-Wei Zhou, Kong-Gang Qu, Yu-Xia Kong, Xian-Qiang Huang and Xian-Xi Zhang performed the experiments. Pei-Pei Luo and Bao-Li Chen analyzed the data. Pei-Pei Luo, Bao-Li Chen, Xian-Xi Zhang and Jia-Xing Lu wrote the paper.

Conflicts of Interest: The authors declare no conflict of interest.

\section{References}

1. Karl, T.R.; Trenberth, K.E. Modern global climate change. Science 2003, 302, 1719. [CrossRef] [PubMed]

2. Sakakura, T.; Choi, J.C.; Yasuda, H. Transformation of carbon dioxide. Chem. Rev. 2007, 107, 2365-2387. [CrossRef] [PubMed]

3. Habisreutinger, S.N.; Schmidt-Mende, L.; Stolarczyk, J.K. Photocatalytic reduction of $\mathrm{CO}_{2}$ on $\mathrm{TiO}_{2}$ and other semiconductors. Angew. Chem. Int. Ed. 2013, 52, 7372-7408. [CrossRef] [PubMed]

4. Zhao, Y.; Yu, B.; Yang, Z.; Zhang, H.; Hao, L.; Gao, X.; Liu, Z. A protic ionic liquid catalyzes $\mathrm{Co}_{(2)}$ conversion at atmospheric pressure and room temperature: Synthesis of quinazoline-2,4(1 h,3 h)-diones. Angew. Chem. Int. Ed. 2014, 53, 5922-5925. [CrossRef] [PubMed]

5. Min, X.; Kanan, M.W. Pd-catalyzed electrohydrogenation of carbon dioxide to formate: High mass activity at low overpotential and identification of the deactivation pathway. J. Am. Chem. Soc. 2015, 137, 4701-4708. [CrossRef] [PubMed]

6. Zhang, S.; Kang, P.; Meyer, T.J. Nanostructured tin catalysts for selective electrochemical reduction of carbon dioxide to formate. J. Am. Chem. Soc. 2014, 136, 1734-1737. [CrossRef] [PubMed]

7. Yuan, J.; Liu, L.; Guo, R.R.; Zeng, S.; Wang, H.; Lu, J.X. Electroreduction of $\mathrm{CO}_{2}$ into ethanol over an active catalyst: Copper supported on titania. Catalysts 2017, 7, 220. [CrossRef]

8. Liu, Q.; Wu, L.; Jackstell, R.; Beller, M. Using carbon dioxide as a building block in organic synthesis. Nat. Commun. 2015, 6, 5933. [CrossRef] [PubMed] 
9. Gao, S.; Lin, Y.; Jiao, X.; Sun, Y.; Luo, Q.; Zhang, W.; Li, D.; Yang, J.; Xie, Y. Partially oxidized atomic cobalt layers for carbon dioxide electroreduction to liquid fuel. Nature 2016, 529, 68-71. [CrossRef] [PubMed]

10. Chen, B.L.; Xiao, Y.; Xu, X.M.; Yang, H.P.; Wang, H.; Lu, J.X. Alkaloid induced enantioselective electroreduction of acetophenone. Electrochim. Acta 2013, 107, 320-326. [CrossRef]

11. Chen, B.L.; Tu, Z.Y.; Zhu, H.W.; Sun, W.W.; Wang, H.; Lu, J.X. $\mathrm{CO}_{2}$ as a C1-organic building block: Enantioselective electrocarboxylation of aromatic ketones with $\mathrm{CO}_{2}$ catalyzed by cinchona alkaloids under mild conditions. Electrochim. Acta 2014, 116, 475-483. [CrossRef]

12. Chen, B.L.; Zhu, H.W.; Xiao, Y.; Sun, Q.L.; Wang, H.; Lu, J.X. Asymmetric electrocarboxylation of 1-phenylethyl chloride catalyzed by electrogenerated chiral $\left[\mathrm{Co}^{\mathrm{I}}(\text { salen) }]^{-}\right.$complex. Electrochem. Commun. 2014, 42, 55-59. [CrossRef]

13. Lan, Y.C.; Wang, H.; Wu, L.X.; Zhao, S.F.; Gu, Y.Q.; Lu, J.X. Electroreduction of dibromobenzenes on silver electrode in the presence of $\mathrm{CO}_{2}$. J. Electroanal. Chem. 2012, 664, 33-38. [CrossRef]

14. Wu, L.X.; Wang, H.; Xiao, Y.; Tu, Z.Y.; Ding, B.B.; Lu, J.X. Synthesis of dialkyl carbonates from $\mathrm{CO}_{2}$ and alcohols via electrogenerated $N$-heterocyclic carbenes. Electrochem. Commun. 2012, 25, 116-118. [CrossRef]

15. Xiao, Y.; Chen, B.L.; Yang, H.P.; Wang, H.; Lu, J.X. Electrosynthesis of enantiomerically pure cyclic carbonates from $\mathrm{CO}_{2}$ and chiral epoxides. Electrochem. Commun. 2014, 43, 71-74. [CrossRef]

16. Khoshro, H.; Zare, H.R.; Namazian, M.; Jafari, A.A.; Gorji, A. Synthesis of cyclic carbonates through cycloaddition of electrocatalytic activated $\mathrm{CO}_{2}$ to epoxides under mild conditions. Electrochim. Acta 2013, 113, 263-268. [CrossRef]

17. Feroci, M.; Inesi, A.; Rossi, L. The reaction of amines with an electrogenerated base. Improved synthesis of arylcarbamic esters. Tetrahedron Lett. 2000, 41, 963-966. [CrossRef]

18. Niu, D.F.; Xiao, L.P.; Zhang, A.J.; Zhang, G.R.; Tan, Q.Y.; Lu, J.X. Electrocatalytic carboxylation of aliphatic halides at silver cathode in acetonitrile. Tetrahedron 2008, 64, 10517-10520. [CrossRef]

19. Isse, A.A.; Gennaro, A. Electrocatalytic carboxylation of benzyl chlorides at silver cathodes in acetonitrile. Chem. Commun. 2002, 2798-2799. [CrossRef]

20. Isse, A.A.; Durante, C.; Gennaro, A. One-pot synthesis of benzoic acid by electrocatalytic reduction of bromobenzene in the presence of $\mathrm{CO}_{2}$. Electrochem. Commun. 2011, 13, 810-813. [CrossRef]

21. Isse, A.A.; De Giusti, A.; Gennaro, A.; Falciola, L.; Mussini, P.R. Electrochemical reduction of benzyl halides at a silver electrode. Electrochim. Acta 2006, 51, 4956-4964. [CrossRef]

22. Scialdone, O.; Galia, A.; Errante, G.; Isse, A.A.; Gennaro, A.; Filardo, G. Electrocarboxylation of benzyl chlorides at silver cathode at the preparative scale level. Electrochim. Acta 2008, 53, 2514-2528. [CrossRef]

23. Chen, D.; Fabre, P.L.; Reynes, O. Electrocarboxylation of chloroacetonitrile by a cobalt(I) complex of terpyridine. Electrochim. Acta 2011, 56, 8603-8610. [CrossRef]

24. Feng, Q.; Huang, K.; Liu, S.; Wang, X. Electrocatalytic carboxylation of 2-amino-5-bromopyridine with $\mathrm{CO}_{2}$ in ionic liquid 1-butyl-3-methyllimidazoliumtetrafluoborate to 6-aminonicotinic acid. Electrochim. Acta 2010, 55, 5741-5745. [CrossRef]

25. Tateno, H.; Nakabayashi, K.; Kashiwagi, T.; Senboku, H.; Atobe, M. Electrochemical fixation of $\mathrm{CO}_{2}$ to organohalides in room-temperature ionic liquids under supercritical $\mathrm{CO}_{2}$. Electrochim. Acta 2015, 161, 212-218. [CrossRef]

26. Wang, H.M.; Sui, G.J.; Wu, D.; Feng, Q.; Wang, H.; Lu, J.X. Selective electrocarboxylation of bromostyrene at silver cathode in dmf. Tetrahedron 2016, 72, 968-972. [CrossRef]

27. Zhao, S.F.; Wang, H.; Lan, Y.C.; Liu, X.; Lu, J.X.; Zhang, J. Influences of the operative parameters and the nature of the substrate on the electrocarboxylation of benzophenones. J. Electroanal. Chem. 2012, 664, 105-110. [CrossRef] [PubMed]

28. Wang, H.; He, L.; Sui, G.J.; Lu, J.X. Electrocatalytic reduction of $\mathrm{PhCH}_{2} \mathrm{Br}$ on a Ag-Y zeolite modified electrode. RSC Adv. 2015, 5, 42663-42665. [CrossRef]

29. Sui, G.J.; Sun, Q.L.; Wu, D.; Meng, W.J.; Wang, H.; Lu, J.X. Electrocatalytic reduction of $\mathrm{PhCH}_{2} \mathrm{Cl}_{\text {on }} \mathrm{Ag}$-zsm-5 zeolite modified electrode. RSC Adv. 2016, 6, 63493-63496. [CrossRef]

30. Scialdone, O.; Sabatino, M.A.; Belfiore, C.; Galia, A.; Paternostro, M.P.; Filardo, G. An unexpected ring carboxylation in the electrocarboxylation of aromatic ketones. Electrochim. Acta 2006, 51, 3500-3505. [CrossRef] 
31. Feng, Q.; Huang, K.; Liu, S.; Yu, J.; Liu, F. Electrocatalytic carboxylation of aromatic ketones with carbon dioxide in ionic liquid 1-butyl-3-methylimidazoliumtetrafluoborate to $\alpha$-hydroxy-carboxylic acid methyl ester. Electrochim. Acta 2011, 56, 5137-5141. [CrossRef]

32. Saravanan, K.R.; Chandrasekaran, M.; Suryanarayanan, V. Efficient electrocarboxylation of benzophenone on silver nanoparticles deposited boron doped diamond electrode. J. Electroanal. Chem. 2015, 757, 18-22. [CrossRef]

33. Doherty, A.P. Electrochemical reduction of butyraldehyde in the presence of $\mathrm{CO}_{2}$. Electrochim. Acta 2002, 47, 2963-2967. [CrossRef]

34. Wang, H.; Zhang, G.; Liu, Y.; Luo, Y.; Lu, J. Electrocarboxylation of activated olefins in ionic liquid BMIMBF 4 . Electrochem. Commun. 2007, 9, 2235-2239. [CrossRef]

35. Zhang, K.; Xiao, Y.; Lan, Y.; Zhu, M.; Wang, H.; Lu, J. Electrochemical reduction of aliphatic conjugated dienes in the presence of carbon dioxide. Electrochem. Commun. 2010, 12, 1698-1702. [CrossRef]

36. Li, J.; Inagi, S.; Fuchigami, T.; Hosono, H.; Ito, S. Selective monocarboxylation of olefins at $12 \mathrm{CaO} \cdot 7 \mathrm{Al}_{2} \mathrm{O}_{3}$ electride cathode. Electrochem. Commun. 2014, 44, 45-48. [CrossRef]

37. Yuan, G.Q.; Jiang, H.F.; Lin, C.; Liao, S.J. Efficient electrochemical synthesis of 2-arylsuccinic acids from $\mathrm{CO}_{2}$ and aryl-substituted alkenes with nickel as the cathode. Electrochim. Acta 2008, 53, 2170-2176. [CrossRef]

38. Steinmann, S.N.; Michel, C.; Schwiedernoch, R.; Wu, M.; Sautet, P. Electro-carboxylation of butadiene and ethene over Pt and Ni catalysts. J. Catal. 2016, 343, 240-247. [CrossRef]

39. Yuan, G.Q.; Jiang, H.F.; Lin, C. Efficient electrochemical dicarboxylations of arylacetylenes with carbon dioxide using nickel as the cathode. Tetrahedron 2008, 64, 5866-5872. [CrossRef]

40. Damodar, J.; Krishna Mohan, S.R.; Jayarama Reddy, S.R. Synthesis of 2-arylpropionic acids by electrocarboxylation of benzylchlorides catalysed by $\mathrm{PdCl}_{2}\left(\mathrm{PPh}_{3}\right)_{2}$. Electrochem. Commun. 2001, 3, 762-766. [CrossRef]

41. Fabre, P.L.; Reynes, O. Electrocarboxylation of chloroacetonitrile mediated by electrogenerated cobalt(I) phenanthroline. Electrochem. Commun. 2010, 12, 1360-1362. [CrossRef]

42. Bessel, C.A.; Rolison, D.R. Electrocatalytic reactivity of zeolite-encapsulated Co(salen) with benzyl chloride. J. Am. Chem. Soc. 1997, 119, 12673-12674. [CrossRef]

43. Isse, A.A.; Falciola, L.; Mussini, P.R.; Gennaro, A. Relevance of electron transfer mechanism in electrocatalysis: The reduction of organic halides at silver electrodes. Chem. Commun. 2006, 344-346. [CrossRef] [PubMed]

44. Scialdone, O.; Galia, A.; Filardo, G.; Isse, A.A.; Gennaro, A. Electrocatalytic carboxylation of chloroacetonitrile at a silver cathode for the synthesis of cyanoacetic acid. Electrochim. Acta 2008, 54, 634-642. [CrossRef]

45. Fiori, G.; Rondinini, S.; Sello, G.; Vertova, A.; Cirja, M.; Conti, L. Electroreduction of volatile organic halides on activated silver cathodes. J. Appl. Electrochem. 2005, 35, 363-368. [CrossRef]

46. Isse, A.A.; Sandonà, G.; Durante, C.; Gennaro, A. Voltammetric investigation of the dissociative electron transfer to polychloromethanes at catalytic and non-catalytic electrodes. Electrochim. Acta 2009, 54, 3235-3243. [CrossRef]

47. Durante, C.; Isse, A.A.; Sandonà, G.; Gennaro, A. Electrochemical hydrodehalogenation of polychloromethanes at silver and carbon electrodes. Appl. Catal. B Environ. 2009, 88, 479-489. [CrossRef]

48. Huang, B.; Isse, A.A.; Durante, C.; Wei, C.; Gennaro, A. Electrocatalytic properties of transition metals toward reductive dechlorination of polychloroethanes. Electrochim. Acta 2012, 70, 50-61. [CrossRef]

49. Peverly, A.A.; Karty, J.A.; Peters, D.G. Electrochemical reduction of (1R,2R,3S,4R,5R,6S)-hexachlorocyclohexane (lindane) at silver cathodes in organic and aqueous-organic media. J. Electroanal. Chem. 2013, 692, 66-71. [CrossRef]

50. Mubarak, M.S.; Peters, D.G. Electrochemical reduction of di-, tri-, and tetrahalobenzenes at carbon cathodes in dimethylformamide evidence for a halogen dance during the electrolysis of 1,2,4,5-tetrabromobenzene. J. Electroanal. Chem. 1997, 435, 47-53. [CrossRef]

51. Gennaro, A.; Isse, A.A.; Vianello, E. Solubility and electrochemical determination of $\mathrm{CO}_{2}$ in some dipolar aprotic solvents. J. Electroanal. Chem. 1990, 289, 203-215. [CrossRef]

52. Rondinini, S.; Mussini, P.R.; Muttini, P.; Sello, G. Silver as a powerful electrocatalyst for organic halide reduction: The critical role of molecular structure. Electrochim. Acta 2001, 46, 3245-3258. [CrossRef]

53. Bellomunno, C.; Bonanomi, D.; Falciola, L.; Longhi, M.; Mussini, P.R.; Doubova, L.M.; Di Silvestro, G. Building up an electrocatalytic activity scale of cathode materials for organic halide reductions. Electrochim. Acta 2005, 50, 2331-2341. [CrossRef] 
54. Fedurco, M.; Coppex, L.; Augustynski, J. Ab initio and electrochemical studies on the reductive bond dissociation in haloethanols. J. Phys. Chem. B 2002, 106, 2625-2633. [CrossRef]

55. Rondinini, S.B.; Mussini, P.R.; Crippa, F.; Sello, G. Electrocatalytic potentialities of silver as a cathode for organic halide reductions. Electrochem. Commun. 2000, 2, 491-496. [CrossRef]

56. Zhang, K.; Wang, H.; Zhao, S.F.; Niu, D.F.; Lu, J.X. Asymmetric electrochemical carboxylation of prochiral acetophenone: An efficient route to optically active atrolactic acid via selective fixation of carbon dioxide. J. Electroanal. Chem. 2009, 630, 35-41. [CrossRef]

57. Aishah, A.J.; Hartini, M.A.; Normala, S.; Norhuda, A.M.; Hanis, H.H.N.; Razif, H.M.; Sugeng, T. Carbon dioxide fixation method for electrosynthesis of benzoic acid from chlorobenzene. J. Nat. Gas Chem. 2007, 16, 273-277. [CrossRef]

58. Isse, A.A.; Berzi, G.; Falciola, L.; Rossi, M.; Mussini, P.R.; Gennaro, A. Electrocatalysis and electron transfer mechanisms in the reduction of organic halides at ag. J. Appl. Electrochem. 2009, 39, 2217-2225. [CrossRef]

59. Zhao, S.F.; Wu, L.X.; Wang, H.; Lu, J.X.; Bond, A.M.; Zhang, J. A unique proton coupled electron transfer pathway for electrochemical reduction of acetophenone in the ionic liquid [BMIM] $\left[\mathrm{BF}_{4}\right]$ under a carbon dioxide atmosphere. Green Chem. 2011, 13, 3461-3468. [CrossRef]

60. Frisch, M.J.; Trucks, G.W.; Schlegel, H.B.; Scuseria, G.E.; Robb, M.A.; Cheeseman, J.R.; Scalmani, G.; Barone, V.; Mennucci, B.; Petersson, G.A.; et al. Gaussian 09, Revision C.01; Gaussian, Inc.: Wallingford, CT, USA, 2010.

(C) 2017 by the authors. Licensee MDPI, Basel, Switzerland. This article is an open access article distributed under the terms and conditions of the Creative Commons Attribution (CC BY) license (http:/ / creativecommons.org/licenses/by/4.0/). 